\title{
THE UN-NAMED SILURIAN(?) DOLOMITE FORMATION, BØRGLUM ELV, CENTRAL PEARY LAND
}

\section{H. A. Armstrong and P. D. Lane}

The un-named Silurian(?) dolomite formation, described originally from the upper reaches of the valley of Børglum Elv (fig. 9) by Christie \& Peel (1977, figs. 3, 4) and widely distributed in Peary Land, has received little detailed attention in any of its outcrops. Although these outcrops were visited by R. L. Christie and J. S. Peel in 1974 (Peel \& Christie 1975, Christie \& Peel 1977), P. D. Lane and A. T. Thomas in 1978 and J. E. Mabillard in 1979 (the reports of the last two parties held as unpublished field accounts by GGU), no detailed log of the whole of this formation has been previously published. The section (fig. 9) was chosen $1 / 2 \mathrm{~km}$ south of that measured by Christie \& Peel (1977, fig. 3H) in order to include the base of the formation.

Fig. 9. Index map showing section locality.

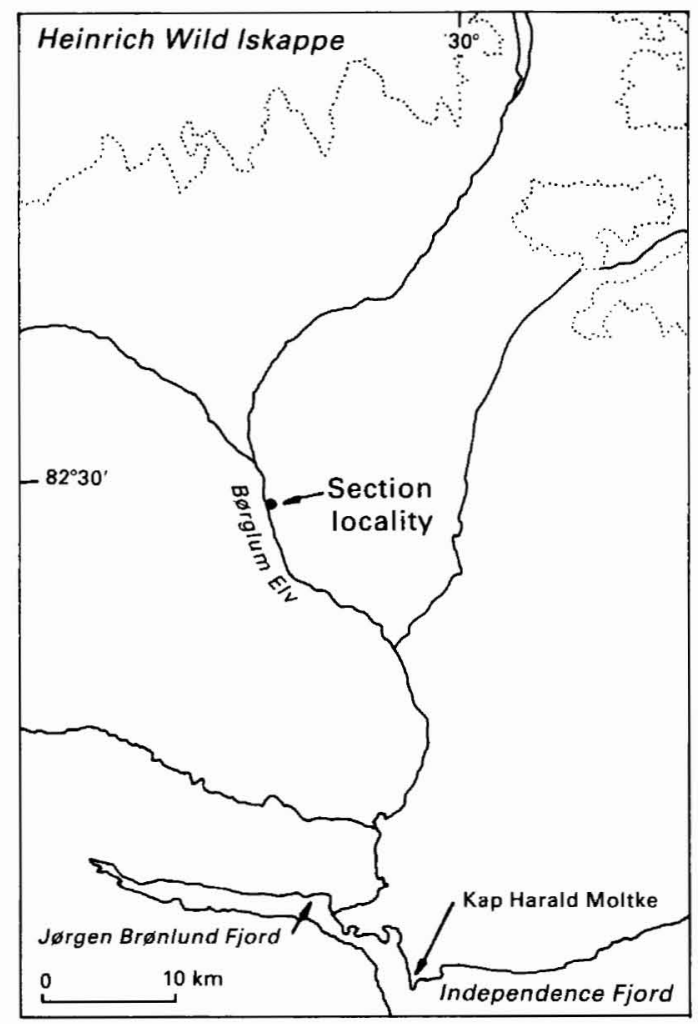




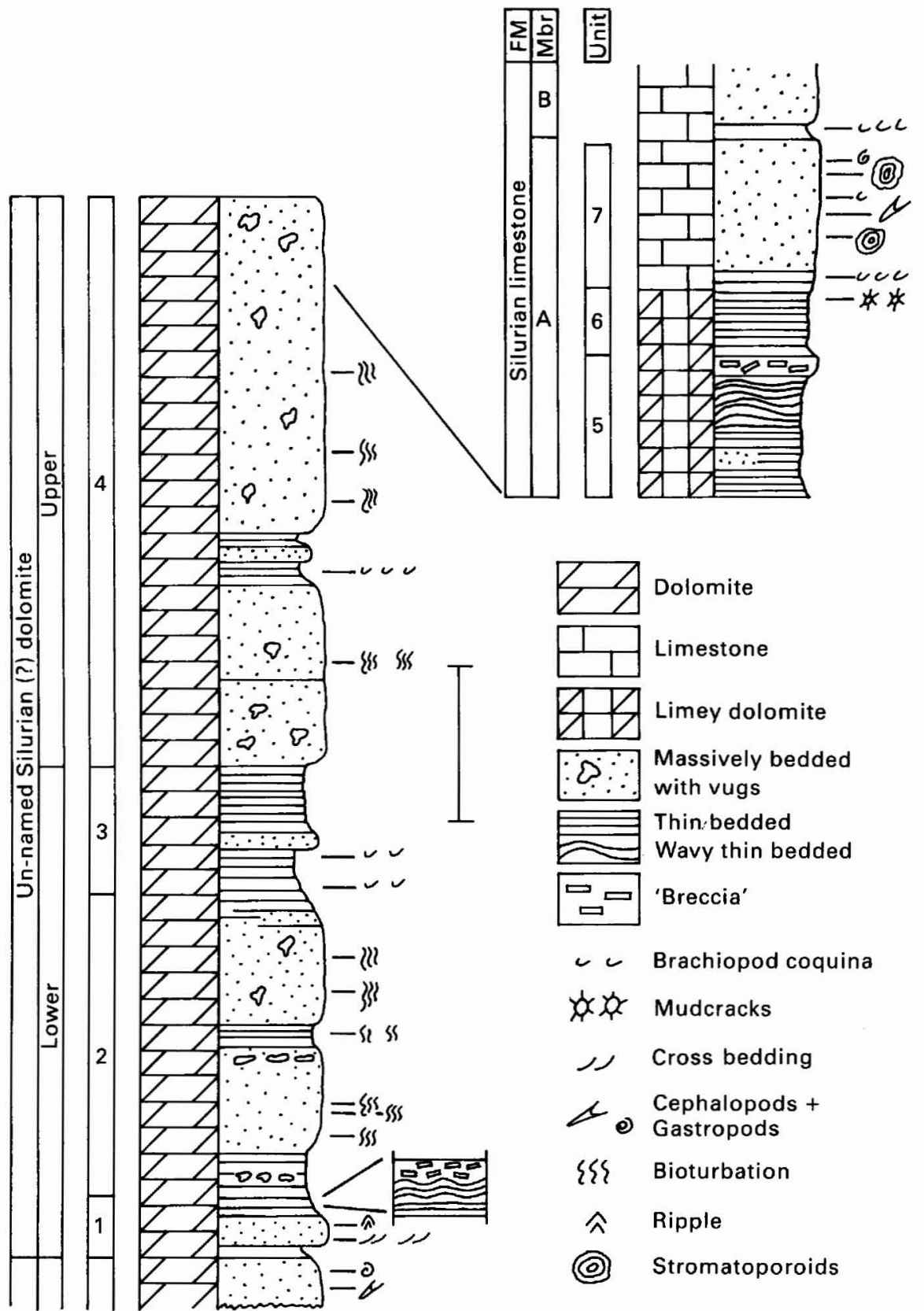

Fig. 10. Lithological log of the un-named Silurian(?) dolomite formation. Scale bar c. $14 \mathrm{~m}$.

We present here a complete log from the upper portion of the Børglum River Formation into the basal part of the un-named Silurian limestone formation, which lie respectively below and above the un-named Silurian(?) dolomite formation (fig. 10). 


\section{Lithostratigraphy}

Lithostratigraphic divisions are taken as in Christie \& Peel (1977).

\section{Børglum River Formation}

The upper $10 \mathrm{~m}$ of this unit were examined. The rocks here are typical of the formation, being massive, dark-weathering limey dolomites with abundant silicified horizontal burrows, Maclurites and actinoceratid cephalopods. Although predominantly dark in colour, the weathered rock is usually mottled in appearance which, perhaps, reflects dolomitization centred on the extensively burrowed original sediment.

\section{Un-named Silurian(?) dolomite formation (c. $95 \mathrm{~m}$ )}

The formation can be divided into four distinct units on the basis of lithology and weathering characteristics. The lowest three units are equivalent to the 'lower member' of Christie $\&$ Peel (1977), and the uppermost to their 'upper member'.

\section{Unit $1($ c. $6 \mathrm{~m})$}

The basal $1 \mathrm{~m}$ of this unit consists of very finely crystalline, almost porcellanous, pale-weathering dolomite which is finely laminated towards the top. Above, $3 \mathrm{~m}$ of medium grey crystalline dolomite show planar and trough cross-bedding. No clear current directions are exhibited by the smaller sets, but the larger ones indicate currents from the southern quadrant. Some bedding planes show scours and faint ripples.

Above this, finely crystalline thin-bedded dolomite passes up into wavy bedded, faintly laminated dolomite which is terminated by a $0.5 \mathrm{~m}$ brecciated horizon. This 'breccia' consists of fragments of finely crystalline, pale dolomite about $10 \mathrm{~mm}$ thick and a few tens of millimetres long, set in a darker, more coarsely crystalline matrix. Commonly fragments have suffered only minimal displacement or rotation; they are closely aligned, one with the next, and fine laminae can be traced easily from one to its neighbours over distances of a few metres.

\section{Unit 2 (c. $28 \mathrm{~m}$ )}

Dark-weathering, massive dolomite with burrow-centred mottling predominates in this unit, although at about half thickness a thin-bedded unit of finely crystalline dolomite occurs. In the massive dolomite, vugs are common and are usually filled with buff dolomite or, rarely, with calcite.

\section{Unit 3 (c. $10 \mathrm{~m})$}

Characteristic of this unit is pale-weathering, porcellanous and finely crystalline dolomite with scattered, randomly oriented, thin-shelled, pentamerid brachiopods, pelmatozoan fragments and smooth-valved ostracods, similar in character to the upper part of Unit 1. 


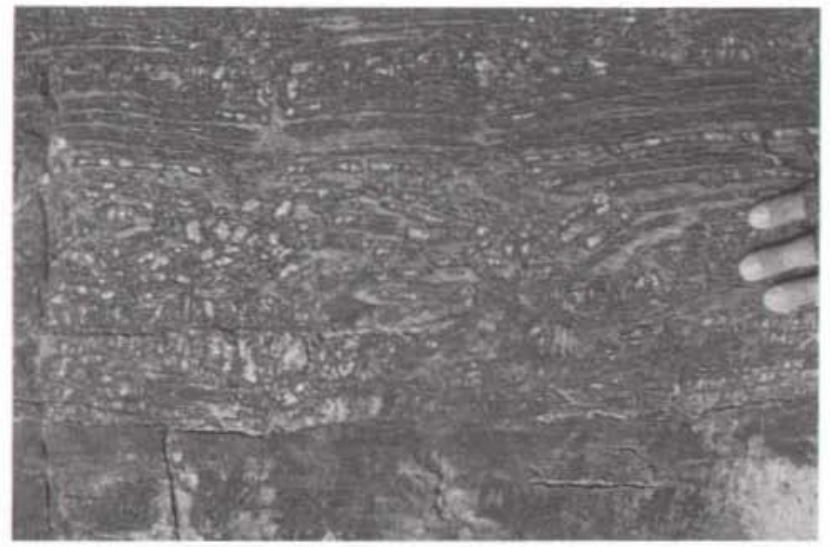

Fig. 11. 'Brecciated' appearance of dolomites at the top of unit 5 of the un-named Silurian limestone formation.

Unit 4 (c. $53 \mathrm{~m})$

This unit consists almost entirely of massive, dark-weathering, dark grey mottled dolomite. It has fine to medium crystallinity with a strong bituminous smell when freshly broken. A few scattered calcite-filled vugs are present, and the general aspect of this unit is like Unit 2.

\section{Un-named Silurian limestone formation (member A)}

Three units (here numbered 5-7) are recognized in member A.

\section{Unit 5 (c. $14.5 \mathrm{~m})$}

Thinly bedded, fine grained, dark limestone and limey dolomite with abundant, smooth ostracods form the basal $6 \mathrm{~m}$ of this unit. Upward the rocks become laminated, at first planar, then wavy and finally brecciated (fig. 11) to resemble those at the top of Unit 1 (see below). In some places localized brecciation, morphologically similar to tepee structure (Shinn, 1969; Evamy, 1973), can be seen, but on a much smaller scale.

\section{Unit $6($ c. $5.5 \mathrm{~m})$}

Very dark, thinly-bedded limestone characterizes this unit. The top few thin beds display well-developed polygonal cracks whose morphology is consistent with an origin due to desiccation (fig. 12).

\section{Unit 7 (c. $15 \mathrm{~m})$}

This unit is composed of massive, blue-grey, medium-grained, bioclastic limestone containing abundant partially silicified brachiopods (mainly thick-shelled pentamerids), gastropods, cephalopods, tabulate corals and stromatoporoids.

Above Unit 7, a $1 \mathrm{~m}$ bed of medium grained calcarenite with very abundant thick-shelled pentamerids, but almost no other fossils, marks the base of Member B of the un-named Silurian limestone formation. 
Fig. 12. Bedding surface in the limey dolomites of Member A of the un-named Silurian limestone formation, showing mud cracks.

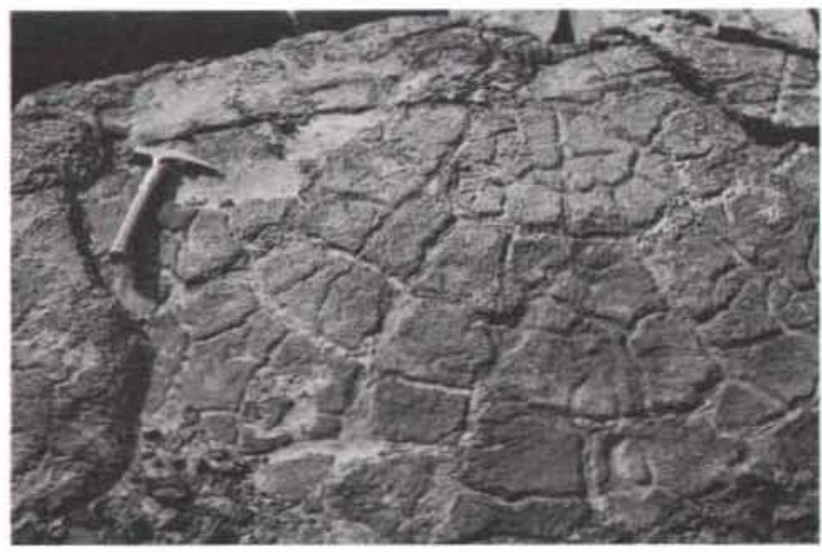

\section{Sedimentary environments}

Rocks with the lithological characters of the Børglum River Formation are commonly formed in a low energy, sheltered, probably subtidal environment as indicated by recent work (Kendall, 1977; Morrow, 1978; Jones, Oldershaw \& Narbonne, 1979) on similar carbonate facies. However, due to the nature of the rocks of the un-named Silurian(?) dolomite formation, and perhaps particularly to the dolomitization, only a few features are preserved with which a detailed analysis of the environments of deposition may be attempted. At the base of the formation, however, the cross-bedded unit indicates higher energy conditions for this interval compared with those under which the Børglum River Formation below accumulated. Shallower water conditions may thus be indicated for the base of the un-named Silurian(?) dolomite formation than for the underlying beds. Further, the poor, restricted to monospecific brachiopod, pelmatozoan or ostracod faunas found sparsely through the un-named Silurian(?) dolomite formation indicate that deposition in an open, fully marine environment is unlikely. Fürsich \& Hurst (1980) indeed, have recently postulated that the character of these faunas, along with regional and stratigraphic considerations, indicate deposition in an "at least slightly hypersaline environment" (p. 306), perhaps lagoonal/intertidal.

In member $\mathrm{A}$ of the un-named Silurian limestone formation (our unit 5) possible small-scale tepee structures are present. Although originally described as typical of supratidal deposits (Shinn, 1969; Evamy, 1973) they have since been recognized in submarine environments in Recent deposits (Till, 1978), so that no specific depth of deposition is necessarily indicated. The extensively developed mudcracks higher in the sequence (our unit 6) afford evidence for at least a short period of emergence to a supratidal environment.

\section{The age of the un-named Silurian(?) dolomite formation}

Christie \& Peel (1977, p. 23) considered that the top of the Børglum River Formation was of early Late Ordovician (Eden-Maysville, 'Red River') age. The un-named Silurian(?) dolomite formation itself has yielded poor brachiopods giving a possible early to middle Llandovery age to its upper part (Christie \& Peel, 1977, p. 24), while Peel (1980, p. 68)

3. Rapport ne. 106 
collected Ordovician fossils from basal beds of the formation in Kronprins Christian Land. Preliminary conodont identifications from the lower part of this formation in Peary Land by R. J. Aldridge and one of us (HAA) has revealed a probable late Ordovician age for the lower $40 \mathrm{~m}$. This evidence suggests that the un-named Silurian(?) dolomite formation contains the Ordovician-Silurian boundary.

\section{Conclusions}

The un-named Silurian(?) dolomite formation is in part of Ordovician and in part of Silurian age. Although it is a shallow marine sequence showing evidence of some shallowing, there is no unequivocal evidence of major relative depth changes in the rocks represented. Brenchley \& Newall (1980) have postulated a marine regression of worldwide extent which occurred at the end of the Ordovician. This regression, it is argued, was represented by a sea level fall of a minimum of $40 \mathrm{~m}$ and a maximum of $170 \mathrm{~m}$, which, it would be expected would produce features in all shallow marine sequences of the relevant age. No evidence of a major regression is seen in the rocks of the section described. The possible regression indicated by the mudcracks in member $\mathrm{A}$ of the un-named Silurian limestone formation is probably of middle Llandovery or younger age, on the evidence of brachiopods from the upper part of the member.

\section{References}

Brenchley, P. J. \& Newall, G. 1980: A facies analysis of Upper Ordovician sequences in the Oslo Region, Norway - a record of glacio-eustatic changes. Palaeogeogr. Palaeoclim. Palaeoecol. 31, 1-38.

Christie, R. L. \& Peel, J. S. 1977: Cambrian-Silurian stratigraphy of Børglum Elv, Peary Land, eastern North Greenland. Rapp. Grønlands geol. Unders. 82, 48 pp.

Evamy, B. D. 1973: The precipitation of aragonite and its alteration to calcite on the Trucial Coast of the Persian Gulf. In Purser, B. H. (edit.) The Persian Gulf, 329-342. Berlin: Springer Verlag.

Fürsich, F. T. \& Hurst, J. M. 1980: Euryhalinity of Palaeozoic articulate brachiopods. Lethaia 13, 303-312.

Jones, B., Oldershaw, A. E. \& Narbonne, G. M. 1979: Nature and origin of rubbly limestone in the Upper Silurian Read Bay Formation of Arctic Canada. Sedim. Geol. 24, 227-252.

Kendall, A. C. 1977: Origin of dolomite mottling in Ordovician limestones from Saskatchewan and Manitoba. Bull. Can. Petroleum Geology 24, 480-504.

Morrow, D. W. 1978: Dolomitization of Lower Paleozoic burrow-fillings. J. sedim. Petrol. 48, 295-306.

Peel, J. S. 1980: Geological reconnaissance in the Caledonian foreland of eastern North Greenland, with comments on the Centrum Limestone. Rapp. Grønlands geol. Unders. 99, 61-72.

Peel, J. S. \& Christie, R. L. 1975: Lower Palaeozoic stratigraphy of southern Peary Land, eastern North Greenland, Rapp. Grønlands Geol. Unders. 75, 21-25.

Shinn, E. A. 1969: Submarine lithification of Holocene carbonate sediments in the Persian Gulf. Sedimentology 12, 108-144.

Till, R. 1978: Arid shorelines and evaporites. In Reading, H. G. (edit.) Sedimentary environments and facies, 178-206. Oxford: Blackwell. 